\title{
WARISAN KEARIFAN LOKAL DALAM TRADISI NAIK JURONG PADA SUKU DAYAK MUALANG DIKABUPATEN SEKADAU
}

\author{
Agnesia Hartini, Fusnika \\ STKIP Persada Khatulistiwa, Pendidikan Pancasila dan Kewarganegaraan, Sintang \\ Email: agnesiahartini21@yahoo.com, funsika804@gmail.com
}

\begin{abstract}
Local wisdom and cultural heritage that develops in rural communities today is a result of the local community habits or society culture as an adaptation to nature and the environment in which they live. This research aims to obtain information about the preservation of local wisdom inheritance in the tradition of Naik Jurong in the Dayak Mualang tribe in Sekadau District.This research used qualitative methods in the descriptive research form. The research subjects were the custom leader, youth leaders, and the Dayak Mualang tribe community. Data collection techniques are carried out by direct observation, interviews and documentation.Local wisdom inheritance in the tradition of Naik Jurong in the Dayak Mualang tribe is an effort to preserve and maintenance the Naik Jurong culture which is still preserved every year after the harvest ends. The elements contained in the Naik Jurong tradition are religious aspects which are a form of gratitude to God for the harvests and aspects of family life, solidarity and unity of the Dayak Mualang tribe community until now.
\end{abstract}

Keywords: Local Wisdom, Naik Jurong, Dayak Mualang 


\begin{abstract}
Abstrak
Kearifan lokal dan warisan budaya yang berkembang di masyarakat pedesaan saat ini adalah merupakan hasil dari kebiasaan masyarakat setempat atau kebudayaan masyarakat sebagai bentuk adaptasi terhadap alam dan lingkungan tempat tinggalnya. Penelitian ini bertujuan memperoleh informasi tentang upaya pelestarian warisan kearifan lokal dalam tradisi Naik Jurong pada suku dayak Mualang di Kabupaten Sekadau. Penelitian ini peneliti menggunakan metode kualitatif dengan bentuk penelitian deskriptif dalam penelitian ini peneliti menggunakan pendekatan kualitatif. Subjek dalam penelitian ini yaitu Ketua Adat, tokoh pemuda, dan masyarakat suku dayak Mualang. Teknik pengumpulan data dilakukan dengan observasi langsung, wawancara dan dokumentasi. Wujud warisan kearifan lokal dalam tradisi Naik Jurong pada masyarakat suku Dayak Mualang merupakan sebuah upaya pelestarian dan pemeliharaan budaya Naik Jurong yang sampai sekarang masih di lestarikan setiap tahun setelah panen berakhir. Adapun unsur yang terkandung dalam tradisi Naik Jurong adalah terdapat aspek religius merupakan wujud syukur berterima kasih kepada Tuhan atas hasil panen yang diperoleh, aspek kehidupan kekeluargaan solidaritas serta pemersatu masyarakat suku dayak Mualang sampai sekarang.
\end{abstract}

Kata kunci: Kearifan Lokal, Naik Jurong, Dayak Mualang 


\section{A. Pendahuluan}

Budaya lokal merupakan proses penumbuhan kreatifitas dari seorang manusia yang aktual dalam menghadapi tantangan sosial penyesuaian keadaan daerah asalnya. Jika dilihat dari banyaknya fenomena yang mana hingga sekarang sangat melekat dengan nyata di tengah masyarakat diantaranya masih adanya tradisi-tradisi yang sangat kental dalam kehidupan masyarakat khususnya pada masyarakat Dayak Mualang yang masih menanamkan nilai-nilai kearifan lokalnya.

Dayak Mualang adalah nama salah satu suku Dayak yang terdapat Kabupaten Sekadau Kalimantan Barat. Kabupaten Sekadau terdiri dari 7 Kecamatan yaitu Kecamatan Sekadau Hilir, Kecamatan Sekadau Hulu, Kecamatan Nanga Taman, Kecamatan Nanga Mahap, Kecamatan Belitang Hilir, Kecamatan Belitang Hulu dan Kecamatan Nanga Belitang. Suku Dayak Mualang sendiri merupakan suku dayak terbesar di Kabupaten Sekadau karena tersebar di 3 Kecamatan yaitu Kecamatan Belitang Hilir, Kecamatan Belitang Hulu dan Kecamatan Nanga Belitang. Dalam menjalankan kehidupannya suku dayak Mualang sangat berpedoman pada kaidah-kaidah yang berlaku diantaranya adat istiadat serta tradisi-tradisi yang masih melekat pada suku dayak Mualang.

Salah satu tradisi lokal suku dayak Mualang yang masih sangat kental dan masih dilaksanakan sampai sekarang adalah tradisi Naik Jurong yang merupakan wujud warisan kearifan lokal suku Dayak Mualang yang terdapat di Kabupaten Sekadau Kalimantan Barat. Kearifan lokal sendiri merupakan pengetahuan, pemahaman, dan kebiasaan yang mengarahkan kehidupan manusia dalam kehidupan masyarakat dalam komunitas ekologis. Kehidupan lokal berguna baik sebagai pengetahuan hidup maupun sebagai perilaku manusia dalam melestarikan lingkungannya (Amri:2013). Naik Jurong adalah istilah lokal masyarakat adat Dayak Mualang yaitu upacara adat ucapan syukur kepada Tuhan atas hasil panen padi yang melimpah pada hasil pertanian, Naik Jurong merupakan puncak dari serangkaian ritual perladangan yang dimaksud untuk memanjatkan rasa syukur kepada Jubata (Tuhan Yang Maha Tinggi).

Naik Jurong ini ditandai dengan memasukan tangkai padi ke dalam 
lumbung (jurong), dengan menyimpan seikat padi yang baru selesai di Panen dalam Jurong (lumbung Padi) oleh setiap kepala keluarga masyarakat Dayak Mulang yang bertani atau berladang. Padi yang disimpang di dalam Jurong nantinya akan dijadikan bibit padi untuk ditanam secara bersama-sama, padi tersebut hasil penen dari ladang dan sawah. Proses meletakan tangkai padi kedalam lumbung padi atau dalam istilah lokal adalah jurong, dan pada saat itu diadakan upacara adat yang disebut nyapat taun atau naik jurong. Artinya memberi makan kepada hasil panen berupa padi dan alat-alat pertanian. Sehingga upacara ini biasa disebut dengan ngumpan atau memberikan sesajian kepada hasil panen. Ritual Naik Jurong menyangkut sistem relegi yang merupakan unsur-unsur kebudayaan.

Naik Jurong selain merupakan sebuah tradisi ucapan syukur kepada Jubata (Tuhan Yang maha Tinggi) juga merupakan wujud warisan kearifan lokal bagi masyarakat suku Dayak Mualang sebagai upaya pelestarian dengan memelihara dan diwariskan dari satu generasi ke generasi yang akan mendatang, Wujud warisan kearifan lokal dalam tradisi Naik Jurong bagi masyarakat suku Dayak Mualang sebagai upaya pelestarian dalam memelihara dan diwariskan dari satu generasi ke generasi yang akan mendatang, mewariskan kebiasaan dari masyarakat suku Dayak Mualang yang memiliki tradisi bercocok tanam, aspek relegius merupakan aspek untuk berterima kasih kepada Tuhan atas hasil panen yang diperoleh dan yang terakhir adalah aspek kehidupan kekeluargaan solidaritas dan pemersatauan yang merupakan aspek menjunjung tinggi nilai kekeluargaan sehingga tradisai Naik Jurong tetap dilakukan oleh masyarakat suku dayak Mualang sampai sekarang.

Dari pemaparan di atas, maka penulis tertarik untuk mengkaji lebih mendalam lagi apakah nilai tradisi naik jurong merupakan wujud warisan kearifan lokal, maka dari itu diangakatlah judul "Warisan Kearifan Lokal Dalam Tradisi Naik Jurong Pada Suku Dayak Mualang Dikabupaten Sekadau.".

\section{B. Metode}

Metode penelitan kualitatif sering disebut juga sebagai metode penelitian naturalistik karena penelitian dilakuakan pada kondisi yang ilmiah (natural setting). Menurut Sugiyono 
(2016 : 1) "metode penelitian ini disebut juga sebagai penelitain etnographi, karena banyak digunakan untuk penelitian bidang antropologi budaya.”. penggunaan metode ini dikarena berkaitan dengan kajian kearifan lokal yang merupakan data-data dari informan. Metode penelitian kualitatif ini dilakukan dalam situasi yang wajar (natural setting) dan data yang dikumpulkan bersifat kualitatif. Menurut Suman dan Akbar (2006), metode kualitatif berusaha memahami dan menafsirkan makna suatu peristiwa interaksi tingkah laku manusia dalam situasi tertentu. Sementara itu Sugiyono (2011) merumuskan definisi metode penelitian yaitu cara ilmiah untuk mendapatkan data dengan tujuan dan kegunaan tertentu.

Jadi metode penelitian adalah langkah - langkah ilmiah yang digunakan dalam mengumpulkan datadata secara ilmiah untuk mencapai sebuah pemahaman untuk dapat dipertanggungjawabkan. Berdasarkan data, fakta dan informasi yang ada dilapangan, maka dalam penelitian ini peneliti menggunakan metode deskriptif kualitatif. Menurut Sugiyono (2011) metode penelitian kualitatif adalah "metode penelitian yang berlandaskan pada filsafat postpositivisme, digunakan untuk meneliti pada kondisi objek yang alamiah". Metode deskriptif kualitatif sebagaimana dikemukakan oleh Nawawi (2012) "metode deskriptif dapat diartikan sebagai prosedur pemecahan masalah yang diselidiki dengan menggambarkan atau melukiskan keadaan subyek atau obyek penelitian pada saat sekarang berdasarkan faktafakta yang tampak, atau sebagaimana adanya.

Dalam penelitian ini peneliti menggunakan pendekatan etnografi, meskipun makna budaya itu sangat luas tetapi studi etnografi biasanya dipusatkan pada pola-pola kegiatan, bahasa, kepercayaan, ritual dan cara-cara hidup. Penelitian ini tergolong penelitian kualitatif, maka subjek penelitiannyamerupakan pihak-pihak yang menjadi saasaran penelitian atau sumber yang dapat memberikan informasi yang dipilih. Dalam penelitian ini yang menjadi subjek penelitian adalah masyarakat, ketua adat, tokoh pemuda suku dayak Mualang. Teknik pengumpulan data dilakukan dengan observasi langsung, wawancara dan dokumentasi. 


\section{Pembahasan Dan Hasil}

\section{Pembahasan}

\section{a. Proses Adat Naik Jurong}

Tradisi Naik jurong merupakan salah satu bentuk keraifan lokal yang masih sanga melekat dalam kehidupan masyarakat khusunya Masyarakat suku dayak Mualang yang terdapat di Kabupaten Sekadau. kesadaran akan adanya keterkaitan kuat dengan Sang Pencipta, memicu rasa syukur atas keberlimpahan padi sebagai kebutuhan pokok bagi penghidupan. Naik Jurong merupakan puncak dari serangkaian ritual perladangan yang dimaksud untuk memanjatkan rasa syukur kepada Jubata (Tuhan Yang Maha Tinggi) yang mempunyai makna syukuran atau berterimakasih kepad Tuhan atas hasil panen yang diperoleh dari sawah atau ladang dan upacara ini dilaksanakan setiap tahun. Dalam tradisi ini juga dipanjatkan doa agar hasil panen padi mendapatkan berkat baik terhadap orang yang menanamnya maupun orang yang memakan hasil pertanian tersebut serta dapat menghasilkan tanaman padi yang bagus dan lebih berlimpah lagi yang akan didapatkan ditahun mendatang melimpah serta dijauhkan dari bencana. Sebuah tradisi yang sakral sebagai wujud kedekatan antar manusia, alam dan
Tuhan-Nya. Suku Dayak Mualang meyakini bahwa alam adalah saudara. selain itu kesadaran manusia kesadaran bahwa manusia berasal dari tanah mengharuskan mereka harus menghormati tanah dan segala yang dihasilkannya. naik

Tradisi Naik Jurong ditandai dengan menyimpan seikat padi yang baru selesai di Panen dalam Jurong (lumbung Padi) oleh setiap kepala keluarga masyarakat Dayang yang bertani/berladang. Padi yang disimpang di dalam Jurong nantinya akan dijadikan bibit padi untuk ditanam secara bersamasama.

Dalam tradisi Nenek Moyang suku Dayak Mualang naik Jurong diawali dengan pertemuan antar penduduk di kampung sehabis panen untuk merencanakan pelakasanaan Naik Jurong terlebih dahulu. pertemuan dilakasanakan beberapa hari sebelum pelaksanaan ritual tersebut diselenggarakan. Setelah diputuskan hari pelaksanaannya, setiap keluarga dikampung sehari sebelumnya memasak beberapa makanan sebagai simbol hasil dari kebudayaan masyarakat diantaranya: beras ketan dimasak dalam buluh (bambu berukuran besar) yang disebut pansoh dan lulun (kue yang 
terbuat dari berat ketan) selain itu disediakan pula daging babi, ayam dan tuak.

Tradisi Naik Jurong merupakan acara yang memiliki 3 aspek kehidupan dalam kehidupan diantaranya aspek kehidupan agraris, aspek relegius, dan aspek kehidupan kekeluargaan solidaritas serta persatuan. Aspek agraris terlihat dari kebiasaan masyarakat suku dayak Mualang yang memiliki tradisi bercocok tanam, aspek relegius merupakan aspek untuk berterima kasih kepada Tuhan atas hasil panen yang diperoleh dan yang terakhir adalah aspek kehidupan kekeluargaan solidaritas dan pemersatauan yang merupakan aspek menjunjung tinggi nilai kekeluargaan.

Acara selanjutya adalah pembacaan doa sebagai perentara antara manusia dan Sang Jubata (Tuhan) yang dilakukan oleh Pemimpin umat. doa-doa yang diucapakan dalam bentuk manteramantera itu berisi pemanggilan pulang semengat padi yang masih berlayar (diperjalanan) agar berkumpul dalam lumbung padi sekaligus sebagai ucapan syukur atas rezeki berlimpah yang diberikan dan memohon berkat untuk menggunakan padi yang sudah disimpan dalam lumbung untuk keperluan pangan. Pesta Naik Jurong biasanya dilakasanakan setelah panen sawah atau ladang selesai yaitu antara bulan Maret sampai akhir april. Dalam upacara tradisi Naik Jurong terdapat para pihak yang terlibat diantaranya Pemimpin umat, ketua adat, tokoh pemuda serta semua masyarakat suku dayak yang berada di wilayah tersebut.

\section{b. Wujud Warisan Kearifan Lokal}

Bangsa besar adalah bangsa yang memiliki karakter kuat yang bersumber dari nilai-nilai digali dari budaya masyarakatnya. Kearifan lokal (merupakan merupakan pembentukan karakter luhur, kearifan-kearifan lokal itulah yang membuat suatu budaya bangsa memiliki akar, membangun jati diri bangsa secara nasional.

Ramli (2008): Kearifan lokal merupakan suatu istilah yang mencuat kepermukaan dengan mengadopsi prinsip, nasehat, tatanan, norma dan perilaku leluhur pada masa lampau yang masih sangat perlu untuk di aplikasikan dalam menata berbagai fenomena yng muncul. Keraifan lokal merupakan bagian dari kontruksi budaya dalam pandangan Jhon Haba dalam Irwan Abdullah (2008) kearifan lokal mengacu pada berbagai kekayaan budaya yang tumbuh dan berkembang dalam sebuah masyarakat yang dikenal, dipercaya dan 
diakaui sebagai elemen-elemen penting yang mampu mempertebal kohensi sosial diantara warga masyarakat.

Kearifan lokal dalam bahasa Inggris disebut local wisdom atau adakalanya juga disebut dengan kata local genius merupakan sebuah istilah yang mulai populer digunakan oleh para pengkaji ilmu sosial. Fahriani (2014) Triminologi ini mengandung semangat untuk melihat, memikirkan dan mempergunakan kembali nilai-nilai norma dan adat yang berlaku disuatu masyarakat yang terlah terwaris secara turun temurun. Istilah ini mengandung dua kata "kearifan" (wisdom) yang bermakna kemampuan menggunakan akal pikiran dan hati dalam menyikapi sesuatu yang lokal yang menunjukan lokasi atau suatu tempat tertentu.

Dalam kamus Inggris Indonesia (Markus Willy Dkk: 1999) local berati setempat, sedangkan wisdom (kearifan) sama dengan kebijaksanaan. Jadi secara umum local wisdom (kearifan setempat atau kearifan lokal) dapat dipahami sebagai gagasan-gagasan setempat yang bijaksana, penuh kearifan, bernilai baik, yang tertanan dan diikuti oleh anggota masyarakat. Kerafian lokal merupakan sesuatu yang telah hidup dan terwariskan dalam masyarakat dan digunakan oleh masyarakat tersebut sebagai alat interaksi dalam kehidupan sehari-hari untuk terwujudnya interaksi sosial ideal yang jauh dari konflik.

Kearifan lokal sendiri memiliki ciri-ciri sebagai berikut: mempunyai kemampuan mengendalikan, merupakan benteng untuk bertahan dari pengaruh budaya luar, mempunyai kemampuan mengakomodasi budaya luar, mempunyai kemampuan memberi arah perkembangan budaya, mempunyai kemampuan mengintegrasi atau menyatukan budaya luar dan budaya asli. Dengan demikian setiap masyarakat memiliki warisan kearifan lokalnya tersendiri yang diikuti oleh masyarakatnya, salah satu wujud warisan kearifan lokal yang bisa kita lihat yaitu terdapat pada masyarakat suku dayak Mualang adalah tradisi Naik Jurong.

Tradisi Naik Jurong merupakan wujud warisan kearifan lokal bagi masyarakat suku Dayak Mualang. Naik Jurong selain merupakan sebuah tradisi ucapaan syukur kepada Jubata (Tuhan Yang Maha Tinggi) juga merupakan wujud warisan kearifan lokal bagi masyarakat suku Dayak Mualang sebagai upaya pelestarian dengan memelihara dan diwariskan dari satu 
generasi ke generasi yang akan mendatang sehingga tradisai Naik Jurong tetap dilakukan oleh masyarakat suku dayak Mualang sampai sekarang. Wujud warisan kearifan lokal bagi masyarakat suku Dayak Mualang sebagai upaya pelestarian dalam memelihara dan diwariskan dari satu generasi ke generasi yang akan mendatang sehingga tradisai Naik Jurong tetap dilakukan oleh masyarakat suku dayak Mualang sampai sekarang. Selain itu tradisi Naik Jurong mewariskan kebiasaan dari masyarakat suku dayak Mualang yang memiliki tradisi bercocok tanam, aspek relegius merupakan aspek untuk berterima kasih kepada Tuhan atas hasil panen yang diperoleh dan yang terakhir adalah aspek kehidupan kekeluargaan solidaritas dan pemersatauan yang merupakan aspek menjunjung tinggi nilai kekeluargaan.

Selain itu terdapat makna penting dalam tradisi Naik Jurong bagi masyarakat suku Dayak Mualang diantaranya sebagai berikut: sebagai ungkapan syukur atas karunia Jubata kepada manusia karena telah memberikan padi yang melimpah sebagai makanan manusi, sebagai permohonan doa restu kepada Jubata (Tuhan) untuk menggunakan padi yang telah disimpan di Jurong padi agar padi yang telah digunakan benar-benar menjadi berkat bagi manusia dan tidak cepat habis, sebagai pertanda penutupan tahun berladang, sebagai sarana memperat hubungan kekeluargaan solidaritas dan pemersatauan.

\section{Simpulan}

Berdasarkan hasil penelitian dan pembahasan secara umum penelitian ini dapat disimpulkan bahwa warisan kearifan lokal dalam tradisi Naik Jurong pada suku dayak Mualang di Kabupaten SekadauWujud warisan kearifan lokal dalam tradisi Naik Jurong bagi masyarakat suku Dayak Mualang sebagai upaya pelestarian dalam memelihara dan diwariskan dari satu generasi ke generasi yang akan mendatang, mewariskan kebiasaan dari masyarakat suku dayak Mualang yang memiliki tradisi bercocok tanam, aspek relegius merupakan aspek untuk berterima kasih kepada Tuhan atas hasil panen yang diperoleh dan yang terakhir adalah aspek kehidupan kekeluargaan solidaritas dan pemersatauan yang merupakan aspek menjunjung tinggi nilai kekeluargaan, sehingga tradisai Naik Jurong tetap dilakukan oleh 
masyarakat suku dayak Mualang sampai sekarang.

\section{Daftar Pustaka}

Akbar, S.P dan H. Usman. 2006. Metode Penelitian Sosial. Bumi Askara. Jakarta

Amri. 2013. Kearifan Lokal Lubuk Larangan Sebagai Upaya Pelestarian Sumberdaya Perairan Didesa Pangkalan Indrarung Kabupaten Kuatan Singing

Irwan Abdullah, dkk. 2008. Agama dan Kearifan lokal dalam tantangan Global. Pascasarjana UGM dan Pustaka Pelajar.Yogyakarta

Fariani. 2014. Nilai pendidikan dalam kearifan lokal permainan tradisional anak Suku Batak dan Melayu. Dalam Bulitin Haba. Banda Aceh. Balai Pelestarian Niali Budaya.
Markus Willy Dkk. 1996. Kamus Inggris Indonesia-Indonesia Inggris. Surabaya. Arloka.

Muhammad Ramli. 2008. Sinergisitas Kearifan Lokal Bugis Dalam Mengimplementasikan

Kebijakan Publik Di Kabupaten Sidenreng Rappang, Disertasi. Universitas Hasanuddin. Makasar.

Nawawi. Hadari. 2012. Metode Penelitian Bidang Sosial. Yogyakarta; Gadjah Mada University Press.

Sugiyono. 2016. Memahami penelitian Kualitatif. Alfabeta. Bandung.

Sugiyono.2011. Metode Penelitian Kuantitatif, Kualitatif dan R\&B. Alfabeta. Bandung. 